\title{
ANTIMICROBIAL ACTIVITY OF NYLON NANOCOMPOSITES AGAINST STAPHYLOCOCCUS AUREUS AND ESCHERICHIA COLI BACTERIA
}

\author{
Rebaz A. Omer ${ }^{\text {a }}$, Aqeel I. Gheni ${ }^{b}$, Karzan A. Omar $^{\text {a }}$, Lana Omer Ahmed ${ }^{\text {c }}$ \\ ${ }^{a}$ Dept. of Chemistry, Faculty of Science \& Health, Koya University, Koya KOY45, Kurdistan Region - F.R. Iraq. (rebaz.anwar; \\ karzan.abdulkareem)@koyauniversity.org \\ ${ }^{\mathrm{b}}$ Dept. of Medical Microbiology, Faculty of Science \& Health, Koya University, Koya KOY45, Kurdistan Region - F.R. Iraq. (aqeel.ismael \\ @ koyauniversity.org) \\ ${ }^{c}$ Dept. of physics, Faculty of Science \& Health, Koya University, Koya KOY45, Kurdistan Region - F.R. Iraq. (lana.omer \\ @koyauniversity.org)
}

Received: Aug., 2019 / Accepted: Nov., 2019/Published: Dec.,2019

https://doi.org/10.25271/sjuoz.2019.7.4.631

\begin{abstract}
:
This research focuses on the properties and applications of inorganic nanostructured materials and their surface modifications, with good antimicrobial activity. In this research, the synthesized nylon 6,10 was saturated with different concentrations of aluminum and titanium oxide nanoparticles to form Nano-composites, which used as an antibacterial agent against both harmful Staphylococcus aureus and Escherichia coli bacteria. The nylon Nano-composites become a good antibacterial agent by inhibition bacteria from growing. Staphylococcus aureus was the inhibition zone 6 to $12 \mathrm{~mm}$ and Escherichia coli from 3 to $11 \mathrm{~mm}$. Concentration of Nano-composites become a powerful inhibitor against both gram-positive and gram-negative bacteria.
\end{abstract}

KEYWORDS: Nylon 6,10, Bacteria, nylon Nano-composites, anti-bacterial agent.

\section{INTRODUCTION}

The polymeric materials have been used in daily life (Rebaz A Omer, Hughes, Hama, Wang, \& Tai, 2015). It has the capability of other components to produce a higher quality product (Rebaz Anwar Omer, Hama, \& Rashid, 2017). Polymer Nano-materials are highly dispersion technologies for the smart design and environmentally friendly. Three components were created Nanocomposition solute, solvent and Nano solvent, each of them is changed decomposition was appeared (Crespy \& Landfester, 2007; Omar, Gheni, Omar, \& Omar). Nylon -6 was modified by clay lamellae to form polymer Nano-composites (nylon -6/clay) the property of polymers attributed to a significant volume of the chains(Nguyen \& Baird, 2006; Shelley, Mather, \& DeVries, 2001). The formation of polymer Nano-composites requires modifying the Nano-layer with appropriate organic surface treatment(Moodley, 2007). Polymer nano-composition leads to increasing application such as the packaging industry (containers, bottles, and plastic films), automotive industry (body parts, exterior, and fuel

tanks), coating industry (wire enamel coating and paints), electronic industry included (exterior parts of devices and packaging materials), and aerospace industry (surface coatings and parts of airplanes)(Fermeglia, Ferrone, \& Pricl, 2002, 2003). Nylon with all types is consisting of polyethylene $(\mathrm{CH} 2) n$ separated by peptide units (NH-CO).

Nylon -n: -[-(NH-CO)-(-CH2)n-1-]- or nylon -m,n: -[-(NH$\mathrm{CO})-(\mathrm{CH} 2) n-2-(\mathrm{CO}-\mathrm{NH})-(\mathrm{CH} 2) \mathrm{m}-]-$

Peptide units of Nylon get it some unique properties such as thermomechanical properties, and unique structural due to provide hydrogen bonding between polymer chains. Two a large volume of nylon or Nylon-6,6 and Nylon- 6 which are used for garments and carpets. Nylon-12 and Nylon-11 are mainly used in injection molding, cable jacketing, tubing extrusion and coating of metal objects (Dasgupta, Hammond, \& Goddard, 1996). Nylon is a polyamide, for synthetic Nylon 6,10 used adipoyl chloride and hexamethylene diamine, that means six carbons between two nitrogen atoms, an amide linkage, another unit of ten carbons (Beecroft \& Ober, 1997). Metal nanoparticles have been used in the various areas such as magnetic(Morey, Bryan, Schwarz, \& Stucky, 2000) catalysis(Ying, Mehnert, \& Wong, 1999) optoelectronic(Schneider et al., 2000) and biomedical materials(Kong \& Jang, 2008). Metal nylon nano-composites use to antibacterial activity. Silver and Zinc Nylon nano-composites were tested against $E$. coli. The effectiveness of fabric as antibacterial observed against $E$. coli bacteria(Omar, Omar, \& Abdullah, 2016; Omar, Smail, \& Omar, 2016). These advanced materials have unique and unusual Physico-chemical properties, such as ultra-small sizes, large surface area/mass ratio, chemical reactivity, and high compatibility for surface modification. Furthermore, the dimensions of Nano-materials and biomolecules (such as small peptides, proteins, and nucleic acids) are generally similar, which allow these particles to exhibit functions and properties that are similar to normal biomolecules present in cellular systems. Nano-materials possess well renowned antimicrobial activity against several microorganisms; however, it has some nonspecific toxicity. The biofunctionalization of Nano-materials is one such subject to address this issue. Rational selection of therapeutically active biomolecules for the design of nanoparticles will certainly increase the biological applicability(Veerapandian \& Yun, 2011). Many metallic have been observed to the growth of bacteria and inactivate enzymes. anti-microbial was shown metals such as silver, zinc, mercury, copper, lead, gold, aluminum and other metals, and the concentration of the metal needed for this antimicrobial effect is extremely small (Jain \& Srinivasan, 1990). 


\section{MATERIAL AND METHODS}

Aluminum oxide $\left(\mathrm{Al}_{2} \mathrm{O}_{3}\right)$, Titanium oxide $\left(\mathrm{TiO}_{2}\right)$, Sebacoyl chloride, and 1, 6 hexamethylene diamine, were provided by the Koya University. The chemical materials) were used without further purification. Distilled water was used for synthesis and measurements. The $\mathrm{TiO}_{2} /$ nylon 6,10 and $\mathrm{Al}_{2} \mathrm{O}_{3}$ /nylon 6,10 Nanocomposites were analyzed by Rigaku NEX CG X-ray fluorescence spectrometer. X-ray fluorescence is an effective method for measuring Aluminum and titanium metals in a sample. The sample was placed in the chamber and measured by a $20 \mathrm{~mm}$ diaphragm in a vacuum. X-ray fluorescence spectra were obtained using $\mathrm{RX} 9, \mathrm{Al}, \mathrm{Cu}$, and Mo conditions. In these analyses, the X-ray tube current was set to approximately $1 \mathrm{~mA}$ for the RX9 target \& $0.5 \mathrm{~mA}$ for other targets. The X-ray tube voltage has been set to $25 \mathrm{kV}$ only for the RX9 and $50 \mathrm{kV}$ for $\mathrm{Al}$ $\mathrm{Cu}$, and Mo, targets. The X-ray fluorescence was measuring 200s for the $\mathrm{Al}$ target and 100s for other targets. Aluminum metals with higher energy equal to $1.5 \mathrm{Kcv}$ and appeared in RX9 targets, but titanium metals with higher energy observed at $4.5 \mathrm{Kcv}$ in a target RX9

\subsection{Synthesis of nylon 6,10 :}

The solution of Sebacoyl chloride $0.5 \mathrm{~g}$ in $100 \mathrm{~mL}$ D.W and the solution of 1,6-hexane diamine $0.5 \mathrm{~g}$ in $100 \mathrm{~mL}$ hexane were prepared. The first solution was added to the second solution to form a mixture. Both acid chloride at the ends of the sebacoyl chloride reacts with both amine ends of the 1,6-diamino hexane to form amide linkages as shown in scheme 1 . The polymer was formed and collected at the interface of the two solutions, which was known as an alternating copolymer (Usuki et al., 1993).

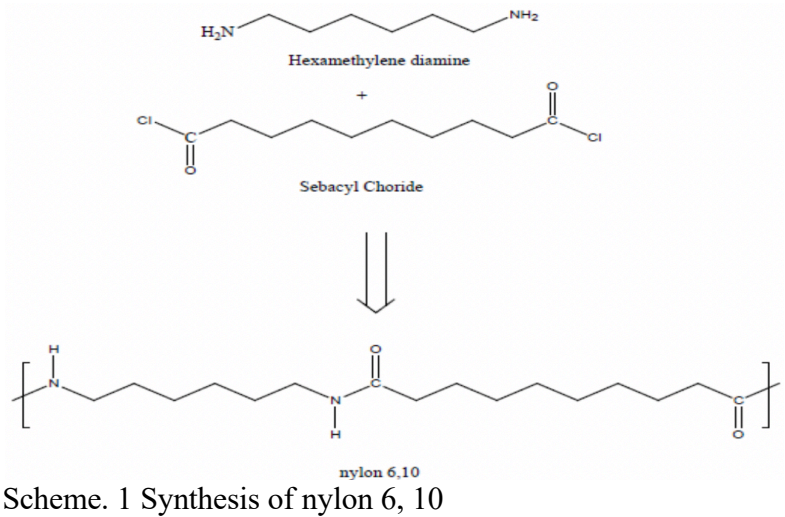

2.2 Synthesis of titanium and aluminum/nylon 6,10 ananocomposition:

A dry piece of nylon 6,10 per weight was used, and immersed in the distilled water for $24 \mathrm{~h}$ to remove all interference and solvent. Nylon was swollen in the different concentrations of aluminum and titanium oxides $(0.5,1$ and $1.5 \mathrm{M})$ and set for 48 hours. The final products were dried in an oven remove at $40{ }^{\circ} \mathrm{C}$ for $12 \mathrm{~h}$. Samples were ready to remove antibacterial tests.

\subsection{Synthesis of titanium and aluminum/nylon 6,10 anano- composition:}

Staphylococcus aureus (ATCC 25923) and Escherichia coli (ATCC 25922), were isolated from Azadi hospital in Erbil/
Kurdistan Region. The cultures at $37^{\circ} \mathrm{C}$ have grown up overnight in blood and MacConkey agar. To identify bacterial were made basted on Gram reaction, Pigmentation, colonial appearance, motility test, and stander biochemical test. These cultures were transferred to tryptic Soya broth medium for $24 \mathrm{~h}$ overnight. Broth culture was diluted in nutrient broth to inoculum load of approximately $1.0 \times 106 \mathrm{cfu} / \mathrm{ml}$. It was standardized by adding gradually normal saline to turbidity compared to McFaland standard of 0.5 which approximately equal to $1.0 * 10^{6}$ according to the standard National Committee for Clinical Laboratory. The antibacterial performance was carried out using the Kirby-Bauer method according to (Anand, Therese, \& Madhavan, 2000; Jones et al., 2003). Individual fresh plates were prepared and incubated at $35{ }^{\circ} \mathrm{C}$ for $24 \mathrm{~h}$. Each isolates discrete colony was transferred into a test tube containing $5 \mathrm{ml}$ of TSB broth and incubated at $37 \mathrm{C}^{\circ}$ overnight. The turbidity of prepared inoculums was closed to $1.0 \times 10^{6} \mathrm{CFU} / \mathrm{ml}$ and inoculum were spread on Muller-Hinton agar medium using a sterile glass spreader, this procedure was repeated by streaked two more times, the plate was rotated approximately $60^{\circ}$ each time to ensure distribution of the inoculums. The plastic Sterile was placed on the culture medium. Plastic was used for control negative, with standard values. Whereas, antibiotic discs as a standard (ciprofloxacin $10 \mu \mathrm{g} / \mathrm{disc}$, Ampicillin \& Cloxacillin 10 $\mu \mathrm{g} / \mathrm{disc} \&$ Vancomycin $10 \mu \mathrm{g} / \mathrm{disc}$ ) were used for control positive. The plates were incubated for 18$24 \mathrm{~h}$ at $37 \mathrm{C}^{\circ}$ and were observed for growth inhibition. After examination of each plate for $16-18 \mathrm{~h}$, the incubation, and circular zones of inhibition were observed. The diameters of the zones of inhibition were measured as judged by the unaided eye. The zones were measured from the surface of the culture medium and illuminated with reflected light. The zone margin was taken as the area showing no obvious, visible growth that can be detected with the unaided eye.

\section{RESULTS AND DISCUSSION}

\subsection{Characterization of $\mathrm{Al}_{2} \mathrm{O}_{3} / \mathrm{Nylon}$ Nanocomposite:}

The x-ray fluorescence is working on the principle that fluorescence absorbing by detectors. Proportion conductance is changed based on the energy of the fluorescence which is processed by the electronic. The horizontal axis determined the fluorescent, which was measured by kilo-electron volts, whereas the vertical axis was measured the intensity per second. The intensity of the fluorescent identified the concentration of the element in a sample while the energy of the fluorescent determined the types of elements in a sample. In the x-ray fluorescent nylon sample without coating by aluminum oxide, the peak of aluminum was not observed as shown in figure 1a. Nylon was coated with different concentrations of aluminum oxide shows peak was observed with different intensity, illustrate in Figure $1 \mathrm{~b}$. The nylon was coated with $0.5 \mathrm{M}$ aluminum oxide the intensity of the peak was lower $16.000 \mathrm{cps}$ compared to figure $1 \mathrm{c}$ and $1 \mathrm{~d}$. The intensity of peaks was equal to 18.000 , and 25.000 cps with concentrations 1 and $1.5 \mathrm{M}$ respectively. 


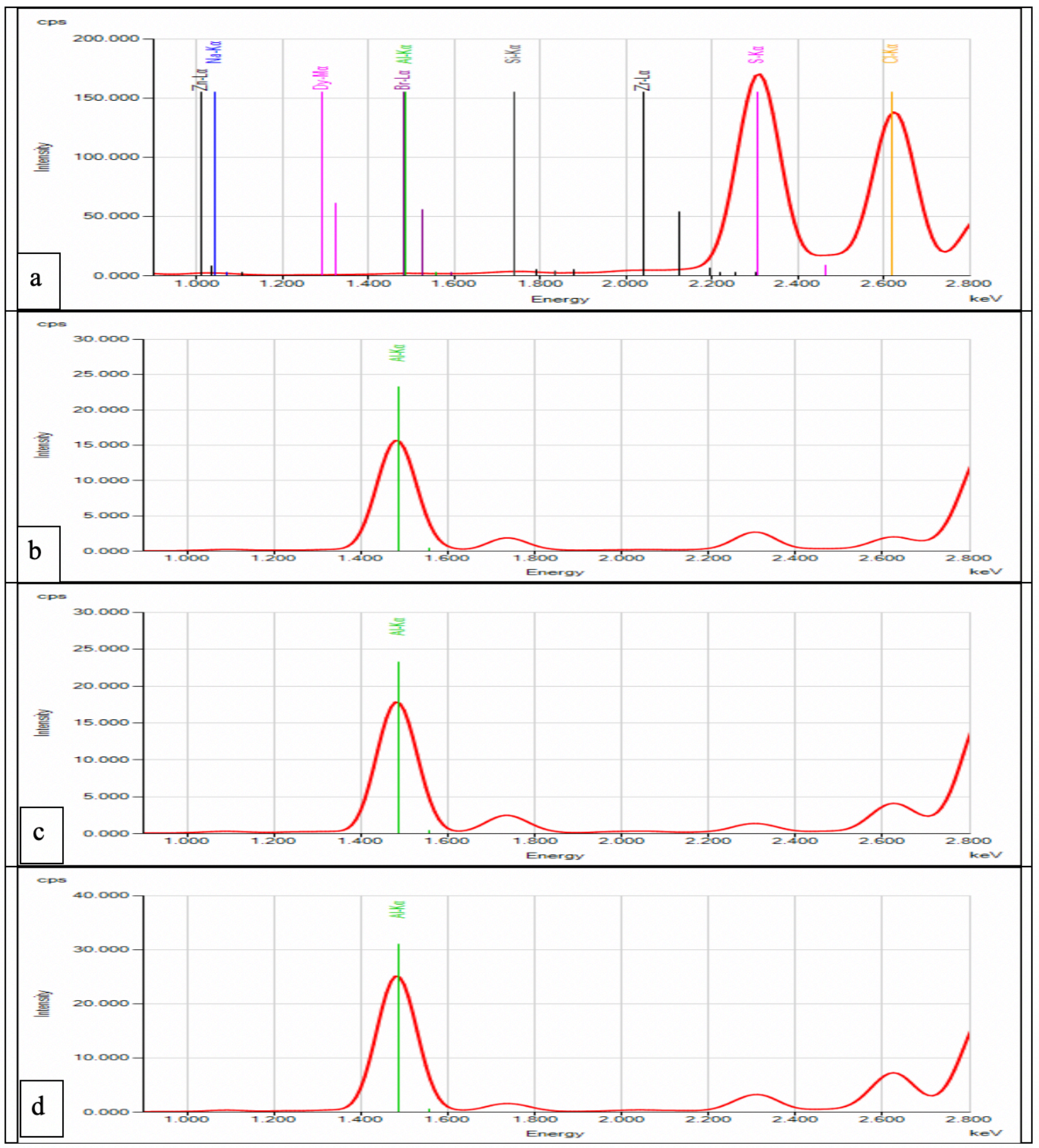

Figure 1. X-ray fluorescence of nylon $/ \mathrm{Al}_{2} \mathrm{O}_{3}$ nanocomposite: (a) Nylon without $\mathrm{Al}_{2} \mathrm{O}_{3}$, (b) $0.5 \mathrm{M} \mathrm{Al}_{2} \mathrm{O}_{3},\left(\right.$ c), $1 \mathrm{M} \mathrm{Al} \mathrm{O}_{3}$, (d) $1.5 \mathrm{MAl}_{2} \mathrm{O}_{3}$.

\subsection{Characterization of tio ${ }_{2} /$ nylon nano-composite:}

Different concentrations of $\mathrm{TiO}_{2} /$ nylon Nano-composite were analyzed by x-ray fluorescence, as can be seen in Figure 2. Nylon without titanium oxide the peak for titanium element was not exhibiting as shown in figure 2a. When Nylon was coated $(0.5 \mathrm{M}) \mathrm{TiO}_{2}$ low intensity was observed, which was equal to more than above $1.000 \mathrm{cps}$ as is shown in Figure $2 \mathrm{~b}$. However, the nylon coated by $(1 \mathrm{M})$ was shown higher intensity for titanium element, which indicated the intensity of titanium increased to $100.000 \mathrm{cps}$ as can be seen in Figure 2c, but for higher concentration $(1.5 \mathrm{M})$, the intensity peak of titanium was increased to above $100.000 \mathrm{cps}$ Fig. 2 d. 

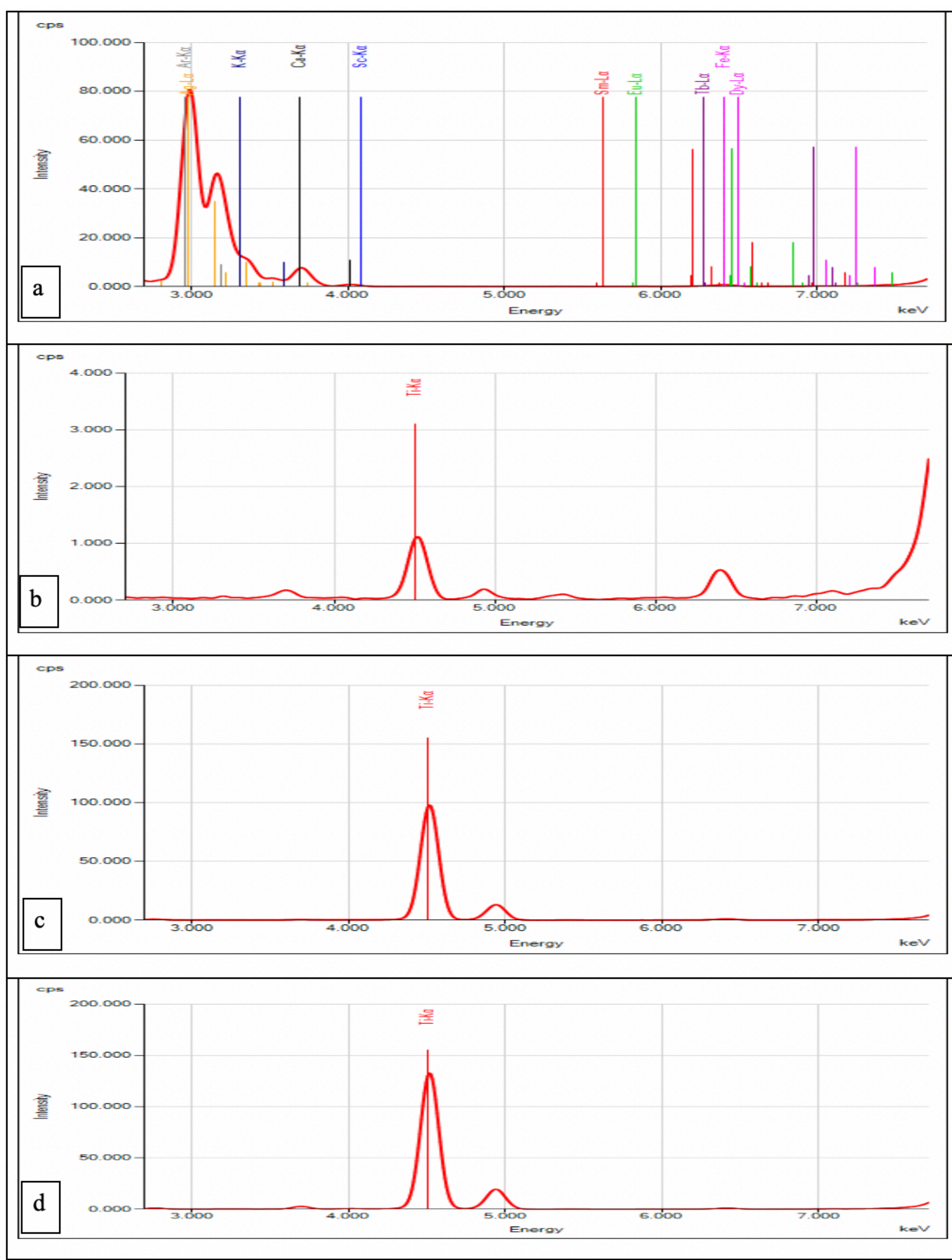

Figure 2. 1 X-ray fluorescence of nylon/ $\mathrm{TiO}_{2}$ nanocomposites: (a) Nylon without $\mathrm{TiO}_{2}$, (b) $0.5 \mathrm{M} \mathrm{TiO}_{2}$, (c), $1 \mathrm{M} \mathrm{TiO}_{2}$, (d) $1.5 \mathrm{M} \mathrm{TiO}_{2}$. 


\subsection{Antibacterial Activity:}

The clear zones were observed, which inhibited microbial growths against of Nano-composite materials. The nylon Nano-composite materials showed an interesting efficacy as an antimicrobial agent against both Staphylococcus aureus and Escherichia coli bacteria. Table 1 shows the antibacterial activity of nylon nano-composites when saturated with both aluminum oxide and tin oxide. The activity of the saturated nylon has been observed as clear zones around the discs which indicated the inhibition of bacteria in the selected area and their diameter of inhibition area increases as the concentration of Nano-composites increases.

Studies with agar well diffusion method revealed maximum antibacterial activity of pure saturated nylon as anti-microbial agents against Staphylococcus aureus was the inhibition zone 6 to $12 \mathrm{~mm}$ and Escherichia coli from 3 to $11 \mathrm{~mm}$ as shown in Figure 3. It can be seen that the zone of inhibition varies from $7 \mathrm{~mm}$ to $15 \mathrm{~mm}$ for both gram-positive and gram-negative bacteria. Bacterial sensitivity to nano-composite is not related only to the structure of the cell wall for both gram-positive and gram-negative bacteria, but it also related to the composition and characteristics of which can influence the susceptibility and tolerance of bacteria too. For instance, Escherichia coli \& Staphylococcus aureus are highly susceptible. (Ashkarran, Ghavami, Aghaverdi, Stroeve, \& Mahmoudi, 2012; Baek \& An, 2011).

Table 1: Inhibition zone of nylon Nano-composites against bacteria

\begin{tabular}{|c|c|c|c|c|c|c|}
\hline \multirow{3}{*}{ Isolates } & \multicolumn{6}{|c|}{ Diameter of zone } \\
\cline { 2 - 7 } & \multicolumn{2}{|c|}{$\begin{array}{c}\text { Nylon -aluminum Nano- } \\
\text { composite }\end{array}$} & \multicolumn{3}{c|}{$\begin{array}{c}\text { Nylon- titanium Nano- } \\
\text { composite }\end{array}$} \\
\cline { 2 - 7 } & $(0.5 \mathrm{M})$ & $(1 \mathrm{M})$ & $\begin{array}{c}(1.5 \\
\mathrm{M})\end{array}$ & $\begin{array}{c}(0.5 \\
\mathrm{M})\end{array}$ & $(1 \mathrm{M})$ & $\begin{array}{c}(1.5 \\
\mathrm{M})\end{array}$ \\
\hline $\begin{array}{c}\text { S. } \\
\text { aureus }\end{array}$ & 9 & 11 & 13 & 3 & 10 & 11 \\
\hline E. coli & 7 & 9 & 10 & 9 & 11 & 15 \\
\hline
\end{tabular}

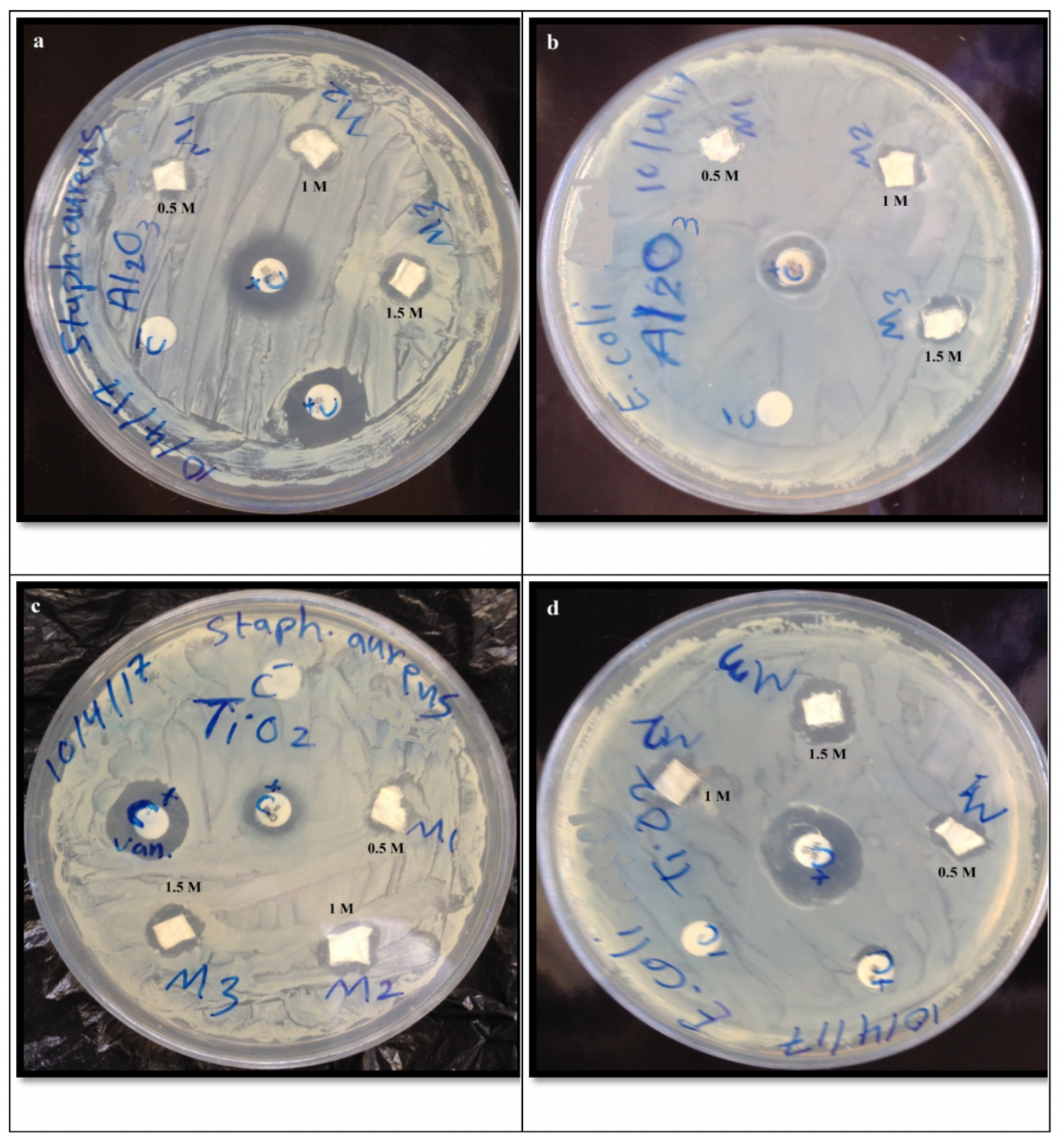

Figure 3. Inhibition zone of nylon Nano-composites against bacteria: a) Nylon- $\mathrm{Al}_{2} \mathrm{O}_{3}$ Nano-composite against Staphylococcus aureus b) Nylon- $\mathrm{Al}_{2} \mathrm{O}_{3}$ Nano-composite against Escherichia coli c) Nylon- $\mathrm{TiO}_{2}$ Nano-composite against Staphylococcus aureus d) Nylon- $\mathrm{TiO}_{2}$ Nano-composite against Escherichia coli and $\mathrm{C}+\mathrm{ve}$ and -ve are controls. 


\section{CONCLUSIONS}

Nylon 6, 10 was synthesized along with nylon Nanocomposites at different concentration and used as an inhibitor agent against Staphylococcus aureus and Escherichia coli bacteria. The Nano-composites showed an interesting inhibition zone with 9 to $13 \mathrm{~mm}$ for Staphylococcus aureus and 7 to $15 \mathrm{~mm}$ for Escherichia coli. The anti-bacterial activity enhanced by increasing the ratio of metal oxides form Nanocomposites with nylon 6, 10. Nylon Nano-composites were characterized by X-ray fluorescence to indicate the intensity of aluminum and titanium metal in the Nano-composites.

This study revealed the sensitivity of nylon 6,10 synthesized nanoparticles toward the microorganisms that are of threatening concern. The study was concluded the toxicity of nylon Nano-composition from one to another species. Also, research was investigating the exact toxicity mechanisms was related to deeply the sensitivity of bacteria to the nanoparticle. More emphasis should be given to the correlation between nylon 6, 10 synthesized Nano-composition structural, chemical properties, optical, electrical, and bacterial toxicity.

\section{ACKNOWLEDGEMENT}

Authors are thankful to chemistry and microbiology Department at Koya University to supporting this work.

\section{REFERENCES}

Anand, A., Therese, K. L., \& Madhavan, H. N. (2000). Spectrum of aetiological agents of postoperative endophthalmitis and antibiotic susceptibility of bacterial isolates. Indian journal of ophthalmology, 48(2), 123.

Ashkarran, A. A., Ghavami, M., Aghaverdi, H., Stroeve, P., \& Mahmoudi, M. (2012). Bacterial effects and protein corona evaluations: crucial ignored factors in the prediction of bioefficacy of various forms of silver nanoparticles. Chemical research in toxicology, 25(6), 1231-1242.

Baek, Y.-W., \& An, Y.-J. (2011). Microbial toxicity of metal oxide nanoparticles $(\mathrm{CuO}, \mathrm{NiO}, \mathrm{ZnO}$, and $\mathrm{Sb} 2 \mathrm{O} 3)$ to Escherichia coli, Bacillus subtilis, and Streptococcus aureus. Science of the total environment, 409(8), 1603-1608.

Beecroft, L. L., \& Ober, C. K. (1997). Nanocomposite materials for optical applications. Chemistry of Materials, 9(6), 13021317.

Crespy, D., \& Landfester, K. (2007). Preparation of nylon 6 nanoparticles and nanocapsules by two novel miniemulsion/solvent displacement hybrid techniques. Macromolecular Chemistry and Physics, 208(5), 457-466.

Dasgupta, S., Hammond, W. B., \& Goddard, W. A. (1996). Crystal structures and properties of nylon polymers from theory. Journal of the American Chemical Society, 118(49), 1229112301.

Fermeglia, M., Ferrone, M., \& Pricl, S. (2002). Nylon-6/organoclay nanocomposites: prediction of the binding energy by molecular simulation. Paper presented at the 16th European Conference on Thermophysical Properties.

Fermeglia, M., Ferrone, M., \& Pricl, S. (2003). Computer simulation of nylon-6/organoclay nanocomposites: prediction of the binding energy. Fluid Phase Equilibria, 212(1-2), 315-329.
Jain, K., \& Srinivasan, N. (1990). An empirical assessment of multiple operationalizations of involvement. ACR North American Advances, (17), 594-602.

Jones, M. E., Karlowsky, J. A., Draghi, D. C., Thornsberry, C., Sahm, D. F., \& Nathwani, D. (2003). Epidemiology and antibiotic susceptibility of bacteria causing skin and soft tissue infections in the USA and Europe: a guide to appropriate antimicrobial therapy. International journal of antimicrobial agents, 22(4), 406-419.

Kong, H., \& Jang, J. (2008). Antibacterial properties of novel poly (methyl methacrylate) nanofiber containing silver nanoparticles. Langmuir, 24(5), 2051-2056.

Moodley, V. K. (2007). The synthesis, structure and properties of polypropylene nanocomposites.

Morey, M., Bryan, J., Schwarz, S., \& Stucky, G. (2000). Pore surface functionalization of MCM-48 mesoporous silica with tungsten and molybdenum metal centers: perspectives on catalytic peroxide activation. Chemistry of materials, 12(11), 3435-3444.

Nguyen, Q. T., \& Baird, D. G. (2006). Preparation of polymer-clay nanocomposites and their properties. Advances in Polymer Technology: Journal of the Polymer Processing Institute, 25(4), 270-285.

Omar, R. A., Gheni, A. I., Omar, K. A., \& Omar, R. A. (2016) Antibacterial Activity of $\mathrm{Zn} /$ Nylon Nanocomposite against Escherichia Coli and Staphylococcus aureus Bacteria, 36, (6),

Omar, R. A., Omar, K. A., \& Abdullah, B. A. (2016). Polyaniline: Synthesis, Characterizations and Study their Antibacterial Activity against Escherichia Coli. Journal of Chemical, Biological and Physical Sciences (JCBPS), 6(2), 510.

Omar, R. A., Smail, A. K., \& Omar, K. A. (2016). Study on the Activity of Ag/Nylon 6, 10 Nanocomposite Against Escherichia coli. Int. J. Curr. Microbiol. App. Sci, 5(4), 935-941.

Omer, R. A., Hama, J. R., \& Rashid, R. S. M. (2017). The effect of dextran molecular weight on the biodegradable hydrogel with oil, synthesized by the michael addition reaction. Advances in Polymer Technology, 36(1), 120-127.

Omer, R. A., Hughes, A., Hama, J. R., Wang, W., \& Tai, H. (2015). Hydrogels from dextran and soybean oil by UV photopolymerization. Journal of Applied Polymer Science, $132(6)$.

Schneider, J. J., Czap, N., Hagen, J., Engstler, J., Ensling, J., Gütlich, P., . . . de Jongh, L. J. (2000). Metallorganic routes to nanoscale iron and titanium oxide particles encapsulated in mesoporous alumina: formation, physical properties, and chemical reactivity. Chemistry-A European Journal, 6(23), 4305-4321.

Shelley, J., Mather, P., \& DeVries, K. (2001). Reinforcement and environmental degradation of nylon-6/clay nanocomposites. Polymer, 42(13), 5849-5858.

Usuki, A., Kojima, Y., Kawasumi, M., Okada, A., Fukushima, Y., Kurauchi, T., \& Kamigaito, O. (1993). Synthesis of nylon 6-clay hybrid. Journal of Materials Research, 8(5), 11791184 .

Veerapandian, M., \& Yun, K. (2011). Functionalization of biomolecules on nanoparticles: specialized for antibacterial applications. Applied microbiology and biotechnology, 90(5), 1655-1667.

Ying, J. Y., Mehnert, C. P., \& Wong, M. S. (1999). Synthesis and applications of supramolecular-templated mesoporous materials. Angewandte Chemie International Edition, 38(12), 56-77. 